\title{
University and Political Awareness among Students: A Study in the Role of University in Promoting Political Awareness
}

\author{
Mohammad Salman Al-Khaza'leh \\ College of Education and Social Sciences, \\ Al-Ain University, Abu Dhabi, UAE \\ Hanene Lahiani \\ College of Education and Social Sciences, \\ Al-Ain University, Abu Dhabi, UAE
}

DOI: https://doi.org/10.36941/jesr-2021-0041

\begin{abstract}
This research work has aimed at investigating the level of political awareness among the Al Ain University students and the role of the university in boosting it by using the descriptive survey method. Indeed, this study has relied upon the questionnaire and the interview as research tools, as well as on the intentional sample where 10 teaching team members were interviewed to answer the third question, and on the random sample where the questionnaire was distributed among 980 students- males and females to answer the first and second questions. The findings of this study revealed that there was a considerably high level of political awareness among the university students. It was also found that there were differences in the level of political awareness among students depending on the faculty, which favoured the students belonging to faculties of humanities. The differences also favoured male students when the variable was gender and 4 th year students when the variable was the year of study. In addition, the study showed that the university played 15 important roles in developing political awareness as was unanimously agreed by the members of the sample. These roles were identified by using recurrences and percentages ranging between 50 and $90 \%$, while those with percentages lower than $50 \%$ were not taken into account.
\end{abstract}

Keywords: political awareness, development, Al Ain University

\section{Introduction}

Politics, Political activity and political awareness are of great significance in the life of societies; they are deeply involved in each and every detail of their daily life. For instance, every single legislation organizing people's life in any field- political, social, educational or other-results from political activity, and their current as well as future life is totally dependent on the political decisions made by political rulers.

In particular, political awareness is one of the main pillars upon which the social and political system is based, and ignoring it throughout the process of the construction of the state will inevitably mean a baseless construction that will collapse immediately when facing any crisis involving the state 
or the society whatever the size of the political or demographic construction. (Fairbrother, 2003.).

Awareness is the total sum of the individual's understanding, knowledge and assessment of things. In fact, awareness grows and develops with the growth and development of the individual's life and therefore results from the various cultural factors affecting the individual. In other words, the better the individual's political culture, the higher his/her political awareness (Abonu, Ogunlade, \&Yunusa, 2013)

The term "awareness", "waai" in Arabic, is derived from "wiaa” which means the inclusion or aggregation of things through conceiving, comprehending and cherishing them. In this way, awareness encompasses the individual's perception of him/herself and of his/her mental and physical functions, his/her perception of the features of the outside world and his/her perception of him/herself as a member of the community (Al Slihat, 2014, p 350).

Conventionally, awareness is defined as the individual's perception of him/herself and of his/her surrounding environment (Al Faitouri, 2020, p 133), whereas political awareness means the citizen's knowledge of his/her political rights and duties, of the events and incidents happening around him/her in addition to his/her capability of wholly recognizing the state of affairs around him/her as a comprehensive truth whose elements are intertwined rather than separate incidents or distanced events.(Kavita, 2017, pp 66-67)

In their study about political awareness among Jordanian students, Althubetat and Jarrar (2013) define political awareness as the "political consciousness, recognizing the political systems and political authorities, being capable of evaluating them at the local, Arab and international levels, and the ability to absorb and respond to and understand the political events » (Althubetat and Jarrar, 2013, pp)

Based on what has been mentioned above, it is clear that political power is the real access to prepare the individual's capabilities, to probate his/her will, to consolidate his/her feeling of freedom and to boost his/her self -esteem in order to achieve human perfection, according to what is suggested by the concepts of comprehensive development which aims at developing and promoting Man.

William, \&Anthony, 2017; Ostrander, Sandler \& Nieman, 2015 and Fiske, Susan., Donald, 2000 insist that political awareness is built and shaped on different levels, such as:

- The theoretical level: It involves the ideas and ideologies included in the subject matter of the awareness such as the cultural values, the criteria and emotions. This level is divided into three phases: the phase of knowledge, perception and discovery, during which the individual is apt for perceiving and understanding truths directly, and which represents the readiness of the awareness to admit the ideas, determine them and select them. Then comes the phase of political interest where the individual shows interest in the community he/she belongs to and preserves its activity, and where the notion of obedience and belonging to that community becomes deep-rooted in him/her. This might be reflected through the numerous activities, deeds, rights and duties that the community imposes on him/her. The third phase is that of political adherence: political awareness requires that the individual adhere intellectually or religiously to a particular group, institution or political establishment. The adherence to these institutions may sometimes steer the individuals' awareness to objectives benefiting the authority or institution the individual belongs to. For instance, when these institutions are compulsory, like school for example, the official awareness of the authority is reflected on that of the students so that they would defend and justify it. However, the individual's adherence to optional groups makes it difficult for the authority to control the awareness of individuals, and the organized awareness of the individuals often emerges in the case of confrontation with the authority.

- The practical level: This level results from the knowledge and experiences that the individual has accumulated which are reflected through his/her relationships with the surrounding environment when he/she passes from the acquisition of knowledge to the level of practice. This is revealed through the individual's contribution to the political process which sometimes leads to the authority's approval of the students' requests and desires. Additionally, if political awareness is a factor that helps with political practice, then its role 
totally depends on a number of conditions mainly the feeling of political aptitude. Indeed, political aptitude is defined as a mental state felt by the individual that he/she has the ability to understand the pertinent aspects in the general social system, so he/she supports them and tries to reinforce and promote them, and to understand the wrong aspects, so he/she tries to criticize them and reveal their negative effects on the individual as well as on the community, and then express his/her well-advised opinion without fear of being blamed or reprimanded.

- Readiness for political participation: this means that the individual's awareness necessitates that the effective practice of political freedom requires the individual to work hand in hand with other members of the political community in order to contribute to drafting policies and decisions and choosing rulers and members of the chambers of deputies both locally and centrally.

- Mutual intellectual tolerance: This means the necessity of the individual's awareness that the effective political practice requires him/her to be willing to contribute with the other members of the political community to the formulation of policies and decisions and to the election of the rulers and the members of the deputy chambers on the regional as well as the central levels.

- The availability of the sense of taking initiatives: Every individual in society has to show a positive feeling towards the state that governs him/her without waiting for the authorities to issue rules and instructions; he/she should be the first to abide by the established laws and rules.

- The people's respect of principles: There has to be a conviction that political power is confided to institutions which are the centre and deposit of power, and that since those institutions are based on political philosophy expressing the community's political conscience, the ruler then is not divine or infallible in any way. Instead, he/she should be respected or disrespected depending on the extent to which he/she adequately serves the principles he/she is entrusted with.

- Mutual trust: there should be mutual trust between the ruler and the ruled on the one hand, and between the ruling political and constitutional institutions on the other hand.

The importance of political awareness is one of the main necessities of life because the formation of the popular political awareness about vital and crucial events and issues helps with the development of societies and paves the way for the institutions of the civil society to be active within those societies, which requires unceasing efforts. The change on the level of awareness cannot be achieved through speeches or writing, instead, there have to be well-studied scientific and logical programmes intended to help achieve that goal. Indeed, it is quite important to think of how to transfer those reformatory ideas to that considerable number of people, on how to assess their effects and on how to control and channel them. This, actually, can only be done through specialized institutions responsible for steering the various life aspects.

Alsati \& Al-Ghanem (2017) stipulate that educational institutions play the biggest role in shaping the individuals' political awareness and practices through their educational approaches and activities, through the lectures and conferences of their teachers and through their educational courses and curricula so that they prepare the individuals to be in charge of public affairs in terms of awareness, contribution and assuming responsibility and enable them to assuredly fulfil their duties and cling to their rights.

The university is such a pioneering institution that it plays a considerable role in empowering its students with political awareness in terms of knowledge, behaviours, traditions and skills ensuring the individual's social and political role. It also promotes his/her national patriotism and nationalism leading to his/her pride in his/her culture, heritage and civilization through the creation of an ideological guidance that fits the ideals and values of his/her society. The university equally plays an important role in the individual's acquisition of various skills and political beliefs in different cultures, countries and institutions (Al Touiresh,v 2012).

As an educational institution, the university has a great influence on the formation of the 
individual, on steering his/her behaviour and on modifying his/her attitudes and tendencies by teaching him/her additional social criteria in the form of new social systems and roles. Indeed, the student learns his/her rights and duties, becomes in full control of his/her emotions and reconciles his/her needs with those of others, in addition to learning cooperation and discipline. Therefore, the university has to strengthen the individual's relationship with the society where he/she lives and to prepare that individual to be a good citizen who can be useful for himself/herself as well as for society through preparing him/her to bear responsibilities, through scientific thinking, through equipping him/her with several inclinations, values and commended customs such as belonging and patriotism and through helping him/her to actually practice those inclinations and values so that they can guide his/her behaviour in the future.

The stability of political regimes, their growth and their development no longer depends on the quantity of natural resources the state has or the amounts of financial means it can make use of; it rather depends on the human resources available to that state and on the educational institutions in particular. The university stands on top of the educational ladder and is in fact responsible for producing the necessary labour forces for the plans of comprehensive development. In the modern view, the university has three main functions, namely: education, scientific research and societal service. Societal service means serving society through culture, renovating it, spreading it and trying to promote it in its society. Like any other social entity, the university may influence and be influenced by the socio-economic, political and security factors; hence its mission should not be restricted to achieving the traditional objectives of education and search for knowledge. Instead, it has to interact with the requirements of society so that it can contribute to uplifting those societies and solving their problems and especially providing a better life for their members through helping them acquire and play their social and political roles in the present and in the future and preparing them for those roles (Solyom, 2011).

Academic education is one of the most substantial means that university uses to educate the youth politically. Besides, universities have a specific philosophy that they use as a springboard for the achievement of their plans and programmes. This philosophy is generally in harmony with that of the state where it belongs as it encompasses principles, values and ideals and emanates from the society's basics and public interests. The educational curriculum is indeed the main means for the transfer of political knowledge and for the formation of concepts, convictions and political tendencies that make the person a good citizen (Al Ghanimeen, 2017)

With their academic expertise and life experience, university teachers are considered one of the mechanisms of political development, for the teacher who involves students in debate and discussions, sets a positive model that would motivate their contribution, interaction and initiatives, while the teacher who is contented by lecturing only develops negative tendencies among students that may become a sort of indifference and nonchalance when they grow up. The university teacher has a chief role in promoting political awareness among students. Thus, if we wanted to develop political awareness among our children, and if we believed in the role that education may play in this regard, nobody would have more capability than the university teacher to reinforce those principles among the youth because the university teacher is in direct contact with the students, knows their way of thinking and is well acquainted with the methods and approaches that help with boosting their thinking and their behaviour. For instance, as the teacher is a bearer, a critic and a guide of the society's main values, principles and traditions, $\mathrm{s} /$ he can transmit cultural and political values through his/her teaching approaches, whether implicitly or explicitly, and therefore can contribute to the development of the youth's political knowledge and to the formation of their concepts, convictions and political tendencies (DeLone, 2014)

Students' organizations also contribute to the students' political education because university offers good opportunities for students' political participation through the elections of students' councils in different colleges, through the conferences and seminars where students converse with teachers, fellow students, guests and authority representatives invited to these events and through allowing students to participate in nationalistic marches which promote loyalty and belonging to one's 
nation state and express the students' attitudes on national and regional political events (Reischl, 2002)

From the aforementioned, it becomes obvious that the analysis of the university education's objectives and of the roles and functions assigned to the university reveal that many of those have a close relation with politics and the political life of both the individual and society. If, among its objectives, the university education aims to promote the student's personal features, to deepen his/her mental and cultural capacities and to give graduation to a generation that is able to hold responsibilities, then political activity requires a balanced personality, an integrated personality and, in particular, mental capacities qualifying the person to engage in the field of political activity.

\section{Research Intricacy and Questions}

Some studies carried out in some Arab countries found out that universities suffered from a failure and a lack of the youth's political involvement as well as the diffusion and promotion of political awareness among them (Al Ajimi, Al Rashidi, 2016)

Educationists emphasize the importance of the role that education plays and its impact on the level of political awareness as it is the most crucial source of this awareness. They also claim that the higher the education stages, the more effective the impact of education on promoting the individual's political awareness. In other words, as the individual passes from one stage to the next higher stage, he/she acquires a deeper awareness than that in the previous stage.

The researchers are interested in this important issue as it reveals the role of the university students because they are considered as a social segment with a distinguished status compared to other youth who did not join universities, and as a selected elite endowed with enough vigour and vivacity to contribute to the building of their society. Accordingly, they have to be one of the effective political forces in society which should give them the necessary attention and care, capitalize on their energy and guide them in a methodically scientific way. To investigate that in Al Ain University and assess whether it is up to the level of the notion of political awareness among students, and to study the university's role in promoting it, the study aims to answer the following research questions:

1. What is the level of political awareness among students according to the students themselves?

2. Are there any statistical differences at the level of $(0.05 \geq \alpha)$ in the political awareness among $\mathrm{Al}$ Ain University students in terms of the gender, college and year of study variables according to the students themselves?

3. What is the role of $\mathrm{Al}$ Ain University in promoting political awareness among students?

\section{Research Objectives}

This research aims to:

1. Investigate the level of students' political awareness in the students' view.

2. Measure the differences in the level of political awareness among Al Ain University students based on the following variables (gender, college and year of study).

\section{Relevance of the Study}

This study derives its relevance from the relevance of the issue investigated which aims to identify the level of students' political awareness, the main pillar on which the social and political system is based. Hence, ignoring the issue of awareness in the process of building the state simply means building on sand bases and therefore this building will not be able to stand when encountering the slightest crisis experienced by the state, whatever the size of the political and demographic construction. As an educational institution, the university plays an important role in highlighting the importance of political awareness in the establishment of the state and society and the reinforcement of this awareness as a solid basis for the democratic experience. For these reasons, the researcher hopes this study can contribute to the provision of information and details to Al Ain University about the students' 
conception of the notion of political awareness and to the assessment of its extent in order to remedy the weaknesses and consolidate the strengths. This can be achieved through revising the education strategies and holding training sessions and workshops that would explain to the students the meaning of political awareness and its importance in the building of the state and society. The researcher also hopes this study will reveal to the university authorities the necessity of avoiding the university's detachment and isolation or neutrality as it is closely related to politics though its other functions are not affected. Similarly, the researcher hopes this research work can contribute to enriching the Arab and Emirati library on this important issue for education and media researchers, and provide facts and data on the importance of political awareness and on the university's role in promoting it.

\section{Limits of the Study}

This study is limited as follows:

Time span: This study was carried out during the second term of the academic year 2019-2020.

Spatial span: This study was applied on a sample of Al Ain University students registered during the second term of 2019 .

\section{Terminology of the Study}

This is a definition of the study terms:

- Awareness

Conventionally: a number of political values, trends and principles allowing the individual to participate effectively in these political trends and principles in dealing with his/her society's problems and state of affairs: this involves analysing them and setting an attitude about them in order to change and develop them (Juihan, $2016: 215$ )

- Political awareness

Political awareness is the comprehensive perception including the political knowledge, values and trends which allow the individual to be well informed about the state of affairs and problems of his/her society, analyse them and set an attitude about them in order to change and develop them.

In execution, it is defined as the grade that the respondent gets on the scale of political awareness that will be developed in this study. It reveals the level of political awareness among AlAin University students on the political events and developments on the local and Arab level.

\section{Previous Studies}

The researcher has surveyed several studies related to the issue of social networks and political awareness, among these studies is the following:

Smith (2018) carried out a study aiming to investigate the impact of short term programs of civic education on the student's political awareness. This study found out that the level of awareness was quite high, and that the students had a negative attitude about political parties and advocated equal opportunity for men and women and for different citizens regardless to their religious background or scientific competence.

Chdevat study (2010) aimed to propose a strategy for the Jordanian universities to promote the concepts of political education among students, and define the role of Jordanian universities in promoting the concepts of political education and the analysis of the nature of the obstacles and means of strengthening the role of Jordanian universities in promoting the concepts of political education among students. The study population consisted of all students in Jordanian universities, public and private, that is (26) Universities for undergraduate and the registered for the second semester of the academic year 2009/2010. The estimated number was (225 602) students, faculty members were (5910), (6) universities were chosen of them (3) official and (3) a private, a sample of (8oo) male and female 
students from these universities was chosen in a soft sample, and the faculty members selected were (350) faculty members from these universities, and the most prominent results of the study revealed positive attitudes among students about the role of universities in promoting the concepts of political education, they also showed the nature of the role and methods of faculty members in dealing with students in the field of political concepts education to form an obstacle in the effectiveness of the Jordanian universities in promoting the concepts of political education .

Adelabo \& Akinsolu (2009), study aimed to find out the role of Nigerian universities in the political education for its students through the curriculum, campus media, peer groups, and lectures, to find out the natural, social and political factors practiced by the students in the university and to highlight the most influential factor in the political culture by the university for its students. The random sample consisting of (1000) students of the Obafemi Awolowo University included (536 new students) and (464) Old students. The questionnaire consisted of two parts first: data on the student and the second: Factors influencing the political education of university. The results showed that students are affected by education policy provided by the university and that impact on the old students is greater than on the new ones, and that there is a statistically significant evidence that the impact of political education in the university on males is greater than on females and the most influential factor on the political culture of the student was the arrangement of the curriculum then the students council then the lectures.

Al Haweela's study (2009) aimed to assess the Kuwaiti University students' political awareness and its relationship with some social changes. The study used a descriptive method and questionnaires distributed among a sample of students from Kuwait University for data collection. The findings showed an average level of political awareness among students in general, that the students of education colleges had a higher level and that female students had a lot to do before they became qualified for political activity.

Aldwaila (2007) conducted a study aimed to measure the degree of political awareness among Kuwaiti women working in higher education, and its impact on the students, and the extent of their knowledge and awareness of the articles of the Constitution, and the importance of the curricula of political education, as well as to identify the role of teachers and the curriculum in the development of political awareness from their point of view. It also aimed to investigate the effect of the variables and the gender of the students and their academic level on the other hand. A selected sample of students consisted of (2782) students and another sample of faculty female members at the University of Kuwait of ( 73 member) were selected by stratified random manner, the result of the study was that the role of teachers and higher education curricula in the development of political awareness among students does not rise to the level required, and showed that there are differences of statistical significance of the degree of political awareness among students due to the gender variable in favor of females and the academic level for the benefit of first-year students .

In a field study conducted by Ahmad (2005) aimed to look in the role of students' activities in the development of political awareness among students, the study was conducted on 620 students from Ain Shams University, the researcher found that there could be a relationship between participating in students' activities and the growth of political awareness, where it is through the mixing of students with each other and their interaction and through committees of various activities.

Knowledge and information are acquired then in turn contribute to the development of their political awareness, their practice of many of direct political activities such as: the nomination of Student Unions, and voting in the student union elections, and the general election, it also includes the Registration for one of the parties, etc., and indirect, such as participating in environmental service projects, writing in wall magazines, and the participation in fund-raising for the Palestinian cause, and doing publicity for a boycott of foreign products, and attending discussions for some political issues through seminars, subscribing in political education camps, all of this in turn contributes to the development of political awareness among students .

Nassar \& Rouaished, 2005, carried out a study aiming to investigate the level of political awareness and nationalism among teacher-students and basic education college in the state of Kuwait using a 
descriptive method and a questionnaire distributed among 311 male and female students. The findings revealed a general weakness in political participation especially among female ones, a positive correlation between participation and the level of nationalism, and a low level of students' political awareness.

(Reischl, 2002)'s study aimed to identify the role of universities in the empowerment of students at the political level and its contribution to the formation a public policy in the country, and the mechanisms of integration and participation of the youth in the development of the community, the study sample consisted of 106 students from a U.S. university, the researcher used the trial method where the study sample was divided into two groups, an officer and a pilot, the pilot group was exposed to a training program that contained several aspects, including conflict resolution, political culture and dealing with the local community, and then the two groups were exposed to situations related to problems in life and issues close to political work, the study concluded the presence of statistically significant differences between the two groups in favor of the pilot group, which confirms the importance of the role of the university in the development and the empowerment of political awareness among students .

What is noticeable after the survey of the previous studies on the local, Arab and world levels is that this study is distinct from the previous ones because of the recent advance of one of the most important issues, political awareness and the investigation of the level of this awareness and the role of the university in promoting it. Indeed, this era of Arab revolutions has witnessed a growing interest in the importance of political awareness, in the transmission of political concepts related to public freedom, human rights and democracy, and in the reinforcement of those notions in the students' behavior scientifically and in practice. It is for these reasons that this study has attempted to investigate this reality, understand it and provide recommendations in this context based on the findings of the study.

\section{Methodology of the Study}

\subsection{The Method}

This study used the descriptive Survey Method and a questionnaire was prepared and developed as a major tool for fact and data collection from the study sample to assess the extent of political awareness among students. Besides, the interview was used when interviewing a number of teaching staff for them to answer about the role of university in promoting students' political awareness.

\subsection{Population of the study}

The population of the study consisted of all $\mathrm{Al}$ Ain University bachelor students registered in the second term of the academic year 2019-2020, as well as of the members of the teaching staff throughout the same term.

\subsection{Sample of the study:}

- The intentional interview was used when interviewing 10 teaching staff members to answer the third question.

- The student sample was taken in random to answer the first question and to highlight the differences in answering the second question where the questionnaire was distributed among 980 male and female students. Tableı specifies the features of the students' study sample in terms of gender, college and year of study. 
Table 1: Distribution of the study's sample members among students in terms of gender, college and academic level

\begin{tabular}{|l|l|c|c|}
\hline Variable & Number & Percentage \\
\hline \multirow{2}{*}{ College } & Humanity & 548 & 0.56 \\
\cline { 2 - 4 } & Scientific & 432 & 0.44 \\
\hline \multirow{3}{*}{ Gender } & Male & 520 & 0.53 \\
\cline { 2 - 4 } & Female & 460 & 0.47 \\
\hline \multirow{4}{*}{ Academic lvele } & First year & 300 & 0.31 \\
\cline { 2 - 4 } & Second year & 216 & 0.22 \\
\cline { 2 - 4 } & Third year & 224 & 0.23 \\
\cline { 2 - 4 } & Fourth year & 240 & 0.24 \\
\hline
\end{tabular}

\subsection{Research tool}

To achieve the objectives of this study, and after examining the literature in a variety of studies, research works, books and resources on the issue of political awareness, the researcher designed a twofold research tool. The first component is the definition of political awareness and covers 28 paragraphs, while the second is an open ended question addressed to the sample of teaching staff members on the role of university in promoting political awareness, and the answers covered 15 paragraphs.

\subsection{Validity of the research tool}

In order to verify the validity of the research tool, the researcher presented the first draft of the questionnaire to 10 specialized referees among the teaching staff in Emirati universities colleges of education sciences. The referees were asked to check the congruity of the paragraphs of the questionnaire paragraphs, the conformity of the paragraphs with the field where they belong and the clarity of the paragraphs and their linguistic accuracy to suggest any modifications they think are necessary, suggest the addition of any paragraphs they think are necessary or the deletion of any paragraphs they think are unnecessary. After arbitration, suggestions recommended by $80 \%$ of the referees were adopted and applied, and in the light of the above-mentioned modifications, the final draft of the questionnaire was presented with 26 paragraphs.

\subsection{Stability of the tool}

After the questionnaire was given to an exploratory sample made up of 45 male and female students not belonging to the study sample, the stability was calculated using Cronbach alpha internal consistency method. It reached $84.5 \%$ in the field of students' perception on the concept of political awareness and $85 \%$ for the role of university in promoting political awareness.

\subsection{Internal Consistency}

The study comprised both dependent and independent variables as follows:

First, independent variables:

College: Humanity / Scientific

Gender: Male / Female

Academic level: First, Second, Third and Fourth year

Secondly, Dependent variables:

The state of political awareness among students / the role of university in promoting it. 


\subsubsection{The statistical methods used}

To answer the research questions, and to check the validity of its hypotheses, the SPSS was used in the analysis. For instance, Descriptive Statistic Measures such as percentages, recurrences, mathematical averages, standard deviations, the One Sample T-Test, the One Way ANOVA analysis and the LCD test were used.

\subsubsection{Adjustment of the research tool}

Likert scale with five graduations to measure compatibility degrees was used as follows: very big (5) degrees, big (4)degrees, medium (3) degrees, small (2) degrees and very small(1) degree. Statistical gradation for the distribution of arithmetic averages is used according to the following equation:

Length of category = $\quad$ length of period

$$
\begin{aligned}
& \text { Length of categories } \\
= & (1-5) / 4 \\
= & 4 \div 5=0.8
\end{aligned}
$$

Consequently, the category distribution has become as follows:

First: $(1-1.80)$ a very small role

Secondly: $(1.81-2.60)$ a small role

Thirdly: $(2.61-3.40)$ a medium role

Fourthly: $(3.41-4.20)$ a big role

Fifthly: $(4.21-5.00)$ a very big role

\section{Findings and Discussion}

Question 1: What is the nature of political awareness among Al Ain University students in their own opinion?

To answer this question, both the arithmetic averages and standard deviations have been drawn out from the answers of the research sample members on the paragraphs related to the nature of

\begin{tabular}{|c|c|c|c|c|c|}
\hline Number & Paragraphs & $\begin{array}{c}\text { Arithmetic } \\
\text { averages }\end{array}$ & \begin{tabular}{|c|} 
Standard \\
deviations
\end{tabular} & Rank & Degree \\
\hline 1 & I try to promote and respect the supremacy of law & $4 \cdot 55$ & 0.19 & 1 & Very big \\
\hline 3 & Realization of the challenges faced by the home nation & 4.27 & 0.94 & 2 & Very big \\
\hline 4 & I understand my duties towards my home nation & 4.25 & 0.94 & 3 & Very big \\
\hline 2 & $\begin{array}{l}\text { I deal positively with political events due to my adherence to } \\
\text { public interest }\end{array}$ & 4.25 & 1.00 & 4 & Very big \\
\hline 6 & $\begin{array}{l}\text { I contribute to the creation of new political horizons with my } \\
\text { colleagues }\end{array}$ & 4.20 & 1.09 & 5 & big \\
\hline 7 & I give priority to public interest over individual interest & 4.18 & 0.95 & 6 & big \\
\hline 5 & I have confidence in the state's official media & 4.13 & 1.01 & 7 & big \\
\hline 25 & I believe in political pluralism & 4.13 & 1.09 & 8 & big \\
\hline 8 & I understand my political and social rights and duties & 4.11 & & 9 & big \\
\hline 9 & $\begin{array}{l}\text { I participate in international relief campaigns to ensure human } \\
\text { brotherhood }\end{array}$ & 4.09 & 1.04 & 10 & big \\
\hline 10 & $\begin{array}{l}\text { I realize that terrorism contributes to the destruction of global } \\
\text { security and peace }\end{array}$ & 4.06 & 1.18 & 11 & big \\
\hline 12 & $\begin{array}{l}\text { I participate in national and religious political ceremonies and am } \\
\text { aware of their importance }\end{array}$ & 4.04 & 1.18 & 12 & big \\
\hline
\end{tabular}
political awareness as shown in table 2

Table 2: Arithmetic averages and standard deviations from the answers of the research sample members 


\begin{tabular}{|c|c|c|c|c|c|}
\hline Number & Paragraphs & \begin{tabular}{|c|}
$\begin{array}{c}\text { Arithmetic } \\
\text { averages }\end{array}$ \\
\end{tabular} & \begin{tabular}{l|} 
Standard \\
deviations
\end{tabular} & Rank & Degree \\
\hline 15 & $\begin{array}{l}\text { I exchange views with my colleagues on values and tendencies } \\
\text { that promote nationalism }\end{array}$ & 4.02 & 1.15 & 13 & big \\
\hline 13 & I interact with the political events in my country & 4.00 & 1.27 & 14 & big \\
\hline 11 & I endeavour to develop good citizenship & 3.90 & 1.32 & 15 & big \\
\hline 14 & $\begin{array}{l}\text { I endeavour to contribute to the promotion of national unity in } \\
\text { my country }\end{array}$ & 3.89 & 1.32 & 16 & big \\
\hline 16 & $\begin{array}{l}\text { I try to reinforce the principle of democracy through my } \\
\text { participation in elections }\end{array}$ & 3.88 & 1.44 & 17 & big \\
\hline 17 & $\begin{array}{l}\text { I pride myself on my university and on preserving it out of respect } \\
\text { and belonging to my home nation }\end{array}$ & 3.87 & 1.34 & 18 & big \\
\hline 18 & $\begin{array}{l}\text { I participate in the organization and preparation of sensitizing } \\
\text { campaigns on national icons }\end{array}$ & 3.86 & 1.37 & 19 & big \\
\hline 20 & $\begin{array}{l}\text { I am aware of and I understand the challenges that the UAE and } \\
\text { other Arab countries face }\end{array}$ & 3.82 & 1.31 & 20 & big \\
\hline 19 & I take part in the students' elections in my college & 3.80 & 1.00 & 21 & big \\
\hline 21 & $\begin{array}{l}\text { I try hard to create a suitable atmosphere for competition } \\
\text { between political movements to raise their tendencies and } \\
\text { thoughts }\end{array}$ & 3.40 & 1.43 & 23 & medium \\
\hline 23 & $\begin{array}{l}\text { I endeavour to consolidate the respect for human rights and the } \\
\text { value of tolerance among citizens }\end{array}$ & 3.38 & 1.43 & 24 & medium \\
\hline 22 & $\begin{array}{l}\text { I try to help with the debates and free discussions between } \\
\text { students at university }\end{array}$ & $3 \cdot 33$ & 1.44 & 25 & medium \\
\hline 24 & $\begin{array}{l}\text { I encourage students of different universities to communicate } \\
\text { through the universities' electronic sites }\end{array}$ & $3 \cdot 30$ & 1.43 & 26 & medium \\
\hline \multirow[t]{2}{*}{26} & I try hard to boost and encourage the spirit of team work & 3.25 & & 27 & \\
\hline & Total & 3.78 & 0.53 & --- & big \\
\hline
\end{tabular}

It can be noticed from the data in table 2 that the highest paragraph in terms of arithmetic average and standard deviation based on the students' responses and their convictions is paragraph 1 that reads as follows: "I try to promote and respect the supremacy of law." Indeed, its arithmetic average was (4.55) and its standard deviation was (o.94) and therefore reflected a very big degree of the nature of political awareness. As for paragraph 26- "I try hard to boost and encourage the spirit of team work", it got the lowest arithmetic average with (3.25) and reflected a medium degree of political awareness. The overall field, however, reflected a big degree of political awareness among students, as the arithmetic average was (3.78). This obviously shows that students are quite knowledgeable and aware of the challenges that the state encounters and deal positively with the political events out of their adherence to the public interest. It also shows that the students contribute to the creation of new horizons for students to express their opinions and attitudes, try to urge students to give priority to public interest over individual interest, contribute to the quick influence of the youth by the national events and the concepts of political awareness, to the promotion of positive values such as nationalism and belonging and to the exchange of opinions and tendencies about politicians. These findings confirm Smith, (2018)'s study the results of which revealed a high degree of political awareness, but contradict Al Haweelah, (2009)'s study which showed a generally medium degree of political awareness and that of Nassar and Rowaishid (2005)'s which showed a low degree in the level of students' political awareness.

Concerning the results related to question 2: (Are there any statistical differences at the level of $(0.05 \geq \alpha)$ in the political awareness among $\mathrm{Al}$ Ain University students in terms of the gender, college and academic level variables according to the students themselves?), the $T$ test was used for the independent samples, as well as the mono-contrast analysis through examining the differences between average responses based on the independent variables. Besides, the LCD test was also used as tables 2, 3, 4 and 5show. 


\section{Differences in the Nature of Political Awareness by University}

The $\mathrm{T}$ test was used for the independent variables by testing the differences in the tendencies between colleges (Sciences, humanity) as shown in table (2).

Table (2): Results of T test for the independent samples by testing the differences in the tendencies between colleges

\begin{tabular}{|c|c|c|c|c|c|c|}
\hline Field & College & $\begin{array}{c}\text { Arithmetic } \\
\text { average }\end{array}$ & $\begin{array}{l}\text { Standard } \\
\text { deviation }\end{array}$ & $\begin{array}{l}\text { T value } \\
\text { found }\end{array}$ & $\begin{array}{l}\text { Degree of } \\
\text { freedom }\end{array}$ & $\begin{array}{c}\text { Statistical } \\
\text { significance }\end{array}$ \\
\hline \multirow{2}{*}{ The concept of political awareness } & Humanity & 3.88 & 0.84 & \multirow{2}{*}{2.280} & \multirow{2}{*}{978} & \multirow{2}{*}{${ }^{*} 0.018$} \\
\hline & Science & 3.68 & 0.90 & & & \\
\hline
\end{tabular}

Statistical significance at the level of $(0.05 \geq \alpha)$

The $\mathrm{T}$ test results for the independent samples showed statistically- significant differences at the level of $(0.05 \geq \alpha)$ in the nature of political awareness among students due to the college variable, which favoured students of humanity colleges. This can be attributed to the fact that humanity college students are assigned courses involving mainly political and national aspects, analysis and synthesis and educational issues, which are all about day-to-day life far more than the students of science colleges who focus on the scientific aspect. These findings agree with Al Haweelah (2009)'s study which revealed a higher level of political awareness among students of education colleges.

\subsection{Differences in tendencies by gender}

The $\mathrm{T}$ test was used for the independent samples through testing the differences in tendencies by gender (male, female) as shown in Table 3:

Table (3): T test results for the independent samples to test the differences in tendencies by gender

\begin{tabular}{|l|c|c|c|c|c|c|}
\hline Field & Gender & $\begin{array}{c}\text { Arithmetic } \\
\text { average }\end{array}$ & $\begin{array}{c}\text { Standard } \\
\text { deviation }\end{array}$ & $\begin{array}{c}\text { T value } \\
\text { found }\end{array}$ & $\begin{array}{c}\text { Degree of } \\
\text { freedom }\end{array}$ & $\begin{array}{c}\text { Statistical } \\
\text { significance }\end{array}$ \\
\hline \multirow{2}{*}{ The concept of political awareness } & Male & 3.95 & 0.82 & \multirow{2}{*}{0.628} & 978 & 0.010 \\
\cline { 2 - 5 } & Female & 3.59 & 0.97 & & 0.678 \\
\hline
\end{tabular}

The differences are statistically significant at $(0.05 \geq \alpha)$

The results for the independent samples reveal a statistical significance at (0.05 $\geq \alpha)$ in the nature of political awareness among students in favour of male students. This can be attributed to a general feature of males that their interest in politics and political activity allows them to take leading positions in their country. The study findings confirm those of (Adelabo \& Akinsolu, 2009) which stipulated that the differences favoured males in dealing with the natural, social and political life. However, it disagrees with the Douwailah's (2007) study's results which claimed that the differences in the level of awareness based on the gender variable favoured females.

\subsection{Differences in tendencies by academic level}

The arithmetic averages, standard deviations and mono-contrast analysis were used through testing the differences in tendencies based on the academic level (first, second, third, fourth or further) as shown in Table (4) 
Table (4): Arithmetic averages of tendencies by academic level

\begin{tabular}{|c|c|c|c|}
\hline Field & Academic level & Arithmetic average & Standard deviation \\
\hline \multirow{3}{*}{ Concept of political awareness } & First & 3.68 & 0.97 \\
\cline { 2 - 4 } & Second & 3.70 & 0.92 \\
\cline { 2 - 4 } & Third & 3.73 & 0.89 \\
\cline { 2 - 4 } & Fourth & 3.97 & 0.81 \\
\hline
\end{tabular}

Table (4) shows a variation in arithmetic average, and to explain this, the mono-contrast analysis was used.

Table (5): Mono-contrast analysis results to test the differences in tendencies based on the academic level

\begin{tabular}{|c|c|c|c|c|c|c|}
\hline Field & Source of contrast & \begin{tabular}{|l|} 
Total of \\
squares
\end{tabular} & $\begin{array}{l}\text { Degree of } \\
\text { freedom }\end{array}$ & $\begin{array}{c}\text { Average of } \\
\text { squares }\end{array}$ & \begin{tabular}{|c|}
$(\mathrm{F})$ \\
Value \\
\end{tabular} & $\begin{array}{c}\text { Statistical } \\
\text { significance }\end{array}$ \\
\hline \multirow{3}{*}{ Concept of political awareness } & Between groups & 2.142 & 3 & 0.714 & \multirow[b]{2}{*}{0.864} & \multirow{3}{*}{011} \\
\hline & Within groups & 723.805 & 976 & 0.715 & & \\
\hline & Total & 725.948 & 976 & & & \\
\hline
\end{tabular}

* It is clear from this table that there are statistically-significant differences at $(0.05 \geq \alpha)$ in the nature of political awareness based on the variable of the academic level. To determine the significance of these differences, the (LCD) test was used as Table (6) shows.

Table (6): (LCD) test to determine the significance of differences based on the variable of the academic level

\begin{tabular}{|l|l|c|c|c|c|c|c|}
\hline Field & Academic level & N & Average & First & Second & Third & Fourth \\
\hline \multirow{4}{*}{ Concept of political awareness } & First & 300 & 3.68 & - & $*$ & $*$ & $*$ \\
\cline { 2 - 9 } & Second & 216 & 3.70 & $*$ & - & & \\
\cline { 2 - 9 } & Third & 224 & 3.73 & $*$ & & - & \\
\cline { 2 - 8 } & Fourth & 240 & 3.97 & $*$ & & & - \\
\hline
\end{tabular}

From the above results, it is noticeable that there are statistically-significant differences at the level of $(0.05 \geq \alpha)$ in the views of the study sample members about the nature of political awareness based on the scientific level. The test shows that the differences favoured fourth year students, which can be attributed to the fact that fourth year students have already passed lots of courses appraising politics and political awareness and the importance of the individual's awareness of the political aspects of his/her country. Besides, they analyse the political sides and are aware of the meaning of the home nation and nationalism, the meaning of democracy and the importance of establishing it, the meaning of society and social solidarity and the meaning of interaction with and the evaluation of political events and foreseeing the future through them.

The results of this study are contradictory with those of Dweila's (2007) findings which maintain that the differences in the level of awareness based on the variable of the academic level favoured first year students.

\section{Results and Interpretation of Responses to Question 3}

What is the role of Al Ain University in promoting political awareness among students? To answer this question, ten teaching staff members were interviewed and asked about what role the university plays in promoting political awareness among students. The total points for this role have been calculated after all the points mentioned by each individual respondent were recorded, the recurring paragraphs for each respondent were added up and reformulated and the recurrences were calculated for each 
paragraph as shown by Table (7).

Table (7): Roles, recurrences and percentages

\begin{tabular}{|c|c|c|c|}
\hline Number & Role & Recurrences & Percentages \\
\hline 1 & $\begin{array}{l}\text { The university encourages students and sensitises them of the importance of } \\
\text { constructive criticism in political activity }\end{array}$ & 9 & $90 \%$ \\
\hline 2 & The university encourages students to participate in political meetings & 9 & $90 \%$ \\
\hline 3 & $\begin{array}{l}\text { The university encourages students to find out about the Emirati } \\
\text { constitution and the deriving laws and systems }\end{array}$ & 9 & $90 \%$ \\
\hline 4 & The university emphasizes the feelings of pride in national identity & 8 & $80 \%$ \\
\hline 5 & $\begin{array}{l}\text { The university ensures no political convictions of the teaching staff members } \\
\text { are imposed on students }\end{array}$ & 8 & $80 \%$ \\
\hline 6 & The university emphasizes the respect for laws, systems and instructions & 8 & $80 \%$ \\
\hline 7 & $\begin{array}{l}\text { The university tries to boost political concepts such as the concept of the } \\
\text { state and those of different authorities }\end{array}$ & 8 & $80 \%$ \\
\hline 8 & $\begin{array}{l}\text { The university focuses on establishing national values and tendencies : } \\
\text { justice, equality and freedom }\end{array}$ & 7 & $70 \%$ \\
\hline 9 & $\begin{array}{l}\text { The university emphasizes linking scientific subjects in the curriculum with } \\
\text { the individual and society: knowledge appropriation }\end{array}$ & 7 & $70 \%$ \\
\hline 10 & $\begin{array}{l}\text { The university emphasizes the appropriation of the political dimension in } \\
\text { the curricula }\end{array}$ & 7 & $70 \%$ \\
\hline 11 & $\begin{array}{l}\text { The university emphasizes the importance of the role in the Arab, regional } \\
\text { and international issues }\end{array}$ & 7 & $70 \%$ \\
\hline 12 & $\begin{array}{l}\text { The university focuses on political participation in its methodological } \\
\text { activities }\end{array}$ & 6 & $60 \%$ \\
\hline 13 & $\begin{array}{l}\text { The university organizes a variety of excursions to help students be informed } \\
\text { about national achievements }\end{array}$ & 6 & $6 \%$ \\
\hline 14 & $\begin{array}{l}\text { The university acquaints students with the nature of political situations } \\
\text { encountered by society and with the evaluation of those situations to serve } \\
\text { their national interest }\end{array}$ & 5 & $5 \%$ \\
\hline 15 & $\begin{array}{l}\text { The university gives students the opportunity to participate in the official } \\
\text { activities and in the seminars with political content }\end{array}$ & 5 & $5 \%$ \\
\hline
\end{tabular}

Table (7) shows that recurrences ranged between 50 and 90\%. Indeed, role number (1) which reads as follows: "The University encourages students and sensitises them of the importance of constructive criticism in political activity", got the highest recurrence of $90 \%$, while role number (15) got the lowest recurrence of $50 \%$. The recurrences that got below $50 \%$ were not taken into account. These responses might mean that university focuses on students' education that combines political awareness with national and international values, family, social and international affinity and an education that denounces racism and extremism and that emphasizes tolerance and proximity whatever the home nation, the religion or the colour of the skin. The university also endeavours to establish privacy in the concept of political awareness among students and stresses the set of values that make up this privacy without separating it from modern international civilization, and to help students understand world politics and its current events. This study confirms the findings of (Reischl's, 2002) study which emphasized the importance of the role of university in the development and empowerment of awareness.

\section{Recommendations}

In the light of the study's results, it is recommended to:

1. prepare an adequate space in the university for students' cultural programs and activities to understand and comprehend the vocabulary of the official political culture 
2. organize more festivals, exhibitions and seminars that develop the spirit of citizenship and pride in the achievements of the nation and the community and of being proud of personalities that contributed to the helping of the nation.

3. urge the faculty members to use the values of democracy and democratic behavioral skills within the lectures in the issues of dialogue, debate and collective tasks.

\section{Conclusion}

The researchers emphasize the importance of the topic this study addresses. Awareness constitutes the main pillar on which the political and social system is built. The study deals with the political awareness among students of $\mathrm{Al}$ Ain University and the university's role in its development. The descriptive survey approach was used, with a questionnaire and an interview as a research tool. For the interview, ten faculty members were intentionally sampled. For the questionnaire, 980 students, male and female, were randomly sampled.

The research is twofold. The first part investigated the concept of political awareness using 28 paragraphs while the second part asked an open-ended question to the sampled teaching staff about the role of university in promoting political awareness.

The validity of the study is verified by presenting it to 10 referees and asking them to check the congruity of the paragraphs of the questionnaire paragraphs, the conformity of the paragraphs with the field where they belong and the clarity of the paragraphs and their linguistic accuracy to suggest any modifications they think are necessary, suggest the addition of any paragraphs they think are necessary or the deletion of any paragraphs they think are unnecessary. The suggestions recommended by $80 \%$ of the referees were adopted and applied, and, hence, the final draft of the questionnaire was presented with 26 paragraphs.

The stability of the tools was calculated using Cronbach alpha internal consistency method. To answer the research questions, and to check the validity of the hypotheses, the SPSS was used in the analysis using descriptive statistic measures such as percentages, recurrences, mathematical averages, standard deviations, the One Sample T-Test, the One Way ANOVA analysis and the LCD test were used. The study comprised both dependent and independent variables. The dependent variables consisted of the state of political awareness among students and the role of the university in promoting it. The independent variables are college (humanity / scientific), gender (male / female) and academic level (first/ second/ third/ fourth year).

The results have shown that university students have an important degree of political awareness. This degree varied according to the variable of college to the benefit of the students of humanities, according to the variable of gender to the benefit of males and according to the variable of academic level to the benefit of fourth year students. The study has also shown that the university plays 15 roles in promoting political awareness among the students. These roles were identified by using recurrences and percentages ranging between 50 and $90 \%$.

The study finally recommends that universities prepare an adequate space for students' cultural programs and activities to understand and comprehend the vocabulary of the official political culture; they organize more festivals, exhibitions and seminars that develop the spirit of citizenship and pride in the achievements of the nation; and they urge the faculty members to use the values of democracy and democratic behavioral skills within the lectures in the issues of dialogue, debate and collective tasks.

\section{References}

Abonu, D. N., Ogunlade, F. O., \& Yunusa, B. M. (2013). “Assesment of Political Awareness among students of Social Studies in Nigerian Secondary Schools for citizenship”. International Journal of Education and Research, 1(12)

Ahmad, S. A (2005), "Student activities and their role in the development of political awareness among university students”. Unpublished MA Thesis, Ain Shams University for Girls, Cairo, Egypt. 
Ajmi, N. \& Rashidi, B. (2016) "Political Participation of Students of Basic Education College", Kuwait, Education College Magazine, Al Azhar University (1) 138, pp. 309-344

Al Faituri, S. A.S. (2020) "The level of political awareness among the students of the college of education at Sirt University", Magazine of political sciences and law, Vol (1) 20, pp. 130-153

$\mathrm{Al}$ Ghanimyeen, M. Z. (2017) "The role of the Jordanian University radio in promoting political awareness among students", Magazine of social science studies, Vol (44) 18, pp. 144-177

Al Haweelah, H. (2009) "Political Awareness among Kuwait University students and its relation with some societal changes". Unpublished $\mathrm{PhD}$ thesis, Al Azhar University, College of Education, Cairo

Alsati. A, S. \&Al-Ghanem, A. "The Political Knowledge of University Students (A Comparative Study between Jordan and Libya)", Asian Social Science, Published by Canadian Center of Science and Education, No. 11, 2017, p. p463-479.

$\mathrm{Al}$ Sulaihat, M. (2014) "Arab Spring revolutions and their effect on the political awareness among the Jordanian University in the Central Region", Al Manarah Magazine, Al albayt University, m (20) 4, pp. 345-365

Althubetat, Q. and Jarrar, A. (20013) «The Impact of Teaching Political Science on Political Awareness of Petra University Students: A Jordanian Case » Research on Humanities and Social Sciences 3(6), 112-121

$\mathrm{Al}$ Touiresh, M. (2012) "Political Awareness- Political awareness as a basic factor in building a democratic political regime", Mustansiriya University, Baghdad from http://thenewiraq.com/

DeLone, G. (2014). "Identifying the antecedents of political engagement behavior among young adult college students". Journal of Political Sciences \& Public Affairs, 2(121): 11-23

Dweila, A. E. (2007). "Degree of political awareness among Kuwaiti women working in Higher education and its impact on students". (unpublished Doctoral thesis). University of Jordan

Fairbrother, G. 2003. "The Effect of Political Education and Critical Thinking on Hong Kong and Main Land Chinese university student National Attitudes". British Journal of Sociology of Education, 24(5), 153-178

Fiske, S. T., Donald R. (200o) "The Novice and the Expert: Knowledge Based Strategies in Political Cognition" The Journal of Experimental Social Psychology, 19(4):381-400

Juweehan, A. (2016). "Effectiveness degree of a suggested programme for the promotion of knowledge and political awareness among higher basic stage students in Jordan". (Unpublished master's thesis), Jordan's Amman University of Higher Studies, Amman, Jordan

Kavita,P (2017) "A study of political awareness among senior secondary school students in Fatehabad district". International Journal of Information Movement, 1(12).

Nassar, S.i M. \&Rouaishid, F. A. (2005) "Political Awareness and National Belonging among students of Basic Education College", Kuwait, Magazine of Educational Sciences, National Centre of Research and Progress, Cairo, (12) 1, pp.213-233

Ostrander, J., Sandler, A. \& Nieman, P 2015). "The Influence of Professional Identity and level of empowerment on political participation of MSW students", paper presented at the Society for Social Work and Research 19th Annual Conference, (1) 14-18.

Reischl, T. (2002). "Political Empowerment - Evaluations of an Intervention with University Student Contributors". American Journal of Community Psychology, Vol.30, Issue 6, P.815-823

Simth, A. (2018). "Political socialization in the classroom revisited: The Kids voting program". The Social Science Journal, 35, 29

Solyom, A. (2011), "High School and University Student's Opinion's about Politics", Journal of Comparative Research in Anthropology and Sociology. Vol 24 - 2, p196-287.

Wiliam, B. R., \& Anthony, P., J. B. (2007). "High School Students and their Political views" National Social Science Association. www.nssaus/journals/2007-28-1/2007-28-13.htm 